\title{
Consumption of Meat and the Human Health
}

Umer Ali ${ }^{1}$, Asif Bilal ${ }^{1 *}$, Urooj Fatima ${ }^{1}$, Muhammad Imran Anjum ${ }^{1}$, Iqra Akbar ${ }^{2}$, Muhammad Khuram Sajjad ${ }^{2}$

${ }^{1}$ Department of Zoology, University of Lahore, Sargodha Campus, Sargodha, Pakistan

${ }^{2}$ Department of Zoology, University of Sargodha, Sargodha, Pakistan

Correspondence to: Asif Bilal, Department of Zoology, University of Lahore, Sargodha Campus, Sargodha, Pakistan.

Received date: June 29, 2021; Accepted date: July 8, 2021; Published date: July 15, 2021

Citation: Ali U, Bilal A, Fatima U, et al. (2021) Consumption of Meat and the Human Health. J Med Res Surg 2(3): pp. 1-3. doi: 10.52916/jmrs214050

Copyright: (C2021 Ali U, et al. This is an open-access article distributed under the terms of the Creative Commons Attribution License, which permits unrestricted use, distribution and reproduction in any medium, provided the original author and source are credited.

\section{ABSTRACT}

It has grown into a significant part of the country's economy as well as a primary supply of white meat and nutrition for the average family. People were interrogated by questionnaire. In this, we included all types and every age of people. Many questions were asked. Industry trends in the meat sector contribute to various meat varieties such as beef, mutton, poultry, and camel, among others. The majority of chicken production takes place on large-scale farms throughout Pakistan's provinces. Chicken is emerging meat industry but beef is still at top so far. Fishery is an important part of Pakistan's economy, as it is a significant source of revenue for coastal residents. Red meat is a nutrient-dense diet that contains significant levels of protein, vital amino acids, vitamins, and minerals, including vitamin A, iron, and zinc, all of which are commonly deficient in the world. However, several studies have connected red meat consumption to a variety of health risks, including heart disease, colon cancer, kidney illness, and digestive disorders. So it is requirement to eat only proper cooked meat to escape its harmful effects.

\section{Keywords:}

Health, Beef, Mutton, Poultry, Fish, Harmful

\section{Introduction}

Local meat producers place a premium on quality. Their reputation for good meat is on the line when they sell to the general public [1]. Purchasing beef from a local rancher or farmer supports not just the rancher or farmer, but also the local economy and society. Meat producers that practice sustainable grazing help to remove carbon from the atmosphere and store it in the soil, improving soil quality. Meat that has been obtained straight from a farm or ranch must often be processed at a local butcher shop [2,3]. The majority of butchers and meat shops in the area sell locally produced cattle.

United States Department of Agriculture (USDA) and state rules must be followed when meat is prepared at a local butcher. Labels like "local" "grass-fed," and "organic" require government approval, and the North Dakota Department of Agriculture maintains a list of area butcher shops and processing centers on its website $[4,5]$.

The majority of meat sold in supermarkets and big box stores comes from animals grown in massive feedlots and industrial farms. Before landing in local grocery store coolers, some meat is imported from other nations. Locally produced meat is generally always fresher than meat from other areas, resulting in better flavor. Meat from pasture-raised poultry, cattle, pork, and other animals has significantly higher omega- 3 fatty acids than meat from feedlot animals $[6,7]$. Omega- 3 fatty acids help to protect heart cells and other physiological functions from stress, which can cause problems including breathing problems and high blood pressure. The total fat level of pasture-raised meat is lower than that of feedlot-raised animals. As a result, there are fewer calories in it.

When customers purchase from a rancher, they can expect high-quality, safe food. In turn, the rancher is able to invest in the community. We've heard that eating locally can help the environment by reducing the amount of resources needed to get food to our tables. Aim to eat food that is produced within a specified radius of their residence $[8,9]$.

While eating locally reduces your environmental effect, it is not as significant as some may imagine, and other aspects are more essential. The way food is produced is more important than how far it is delivered, according to a paper from the International Institute for Environment and Development titled "Fair Miles Recharging the Food Miles Map". The quantity of energy, fertilizer, and other resources consumed on the farm may be more important to the environment than the end product's transportation. Food miles aren't usually a reliable metric [10].

Main meals in Pakistan are typically served with wheat bread (roti or naan) or rice. Salad is usually served as a side dish to accompany the main course rather than as an appetizer. At the end of a meal, assorted fresh fruit or desserts are served $[11,12]$. In comparison to other South Asian cuisines, meat plays a much larger role in Pakistani cuisine $[13,14]$.

While purchasing locally produced meat reduces the amount of fuel required to transport your food, it does not change the reality that animal husbandry consumes an excessive amount of resources and generates a significant amount of waste and pollution $[15,16]$. It makes no difference whether they are cultivated locally or imported from across the globe in terms of total emissions. Because transportation accounts for less than $1 \%$ of beef's GHG emissions, eating local has a negligible impact on the whole footprint $[17,18]$.

\section{Objectives}

The aim and objectives of our study were to check the harmful and positive effects of local meats on the human health as well check their nutrients and economy.

\section{Material and Method}

People were interrogated by questionnaire. In this, we included 
all types and every age of people. Many questions were asked The most important questions were; what is the routine diet, do they have any special diet, do you use milk or beverage with meat, Body Mass Index (BMI) before and after regular use, which meat do you prefer (red, poultry, white), source of meat (From where you eat, home or restaurants/hotels), do you have any medical problem, have you ever been afraid of meat use by the physician's advice, what type of meat/meat product usually preferred by you? (fast foods/normally cooked).

\section{Results}

It was a survey based research where our research team interviewed about half of a thousand people. And also we investigated some forms including two poultry, one fish and one cow forms. The results are based on public opinion and some facts and figures $[19,20]$.

We found $96 \%$ non-vegetarian who used meat properly in their diet and $4 \%$ vegetarians who avoid meat. Fish, chicken, mutton and beef meat usually used in our region but mostly chicken meat and its meat products' sale is very high especially in bakery products and fast foods. Fish meat sale increases in winter season but chicken remains at top in both winter and summer [21,22].

In 2011-2012, Pakistan consumed 779,000 tonnes of goat meat, placing it among the top three countries in the world. Pakistan ranks 9th among beef-consuming countries, with 1.7 million tonnes consumed. Furthermore, with 834,000 tonnes of poultry meat consumed, it is among the top 20 countries in the globe. Poultry production has progressively expanded its share of the country's total meat pool. Beef had a 61 percent market share in 1971, mutton had a 37 percent market share, and poultry meat had a 2-2.5 percent market share. Poultry meat's market share climbed to $25 \%$ in 2010 , while beef and mutton's market share decreased to $55 \%$ and $20 \%$, respectively [10].

Industry trends in the meat sector contribute to various meat varieties such as beef, mutton, poultry, and camel, among others $[23,24]$. However, because poultry is a popular meat, greater focus is placed on production strategies, company setup, production, and processing. Pakistan's poultry business, mainly broilers, dominates the industry, accounting for $69.22 \%$ of the country's total livestock [25]. The majority of chicken production takes place on large-scale farms throughout Pakistan's provinces. The primary players, however, are Khyber Pakhtoon-Khwa and Punjab, which each provide a

\section{Consumption of meat annually}

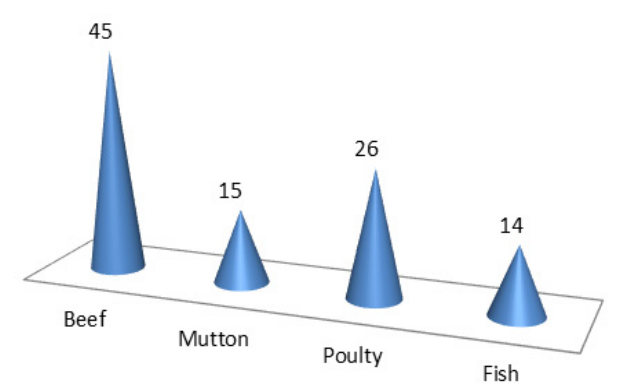

Figure 1: Consumption of meat annually. large percentage of chicken birds. However poultry production increases rapidly. See (Figure 1).

Fishery is an important part of Pakistan's economy, as it is a significant source of revenue for coastal residents $[15,17]$. In addition to sea fisheries, inland fisheries (based in lakes, rivers, dams, and ponds, for example) are becoming increasingly important. Although the contribution of fishing to the country's Gross Domestic Product (GDP) is nominal, it has a significant impact on national growth through overseas export profits. As demand for beef grows, Pakistan has the potential to become a global contender in the halal meat market by adding its red meat business. Due to the availability of resources such as land, agriculture backdrop pastures, Muslim majority population, and intermediate zones of the country, Pakistan has a large scope of cow and goat rearing throughout the year $[12,15]$.

Meat which has low fat but high protein should use to eat to avoid its harmful effects. And if you eat meat it should control $\mathrm{BMI}$ and do workout. People consume meat because it has all essential nutrients. See (Figure 2).

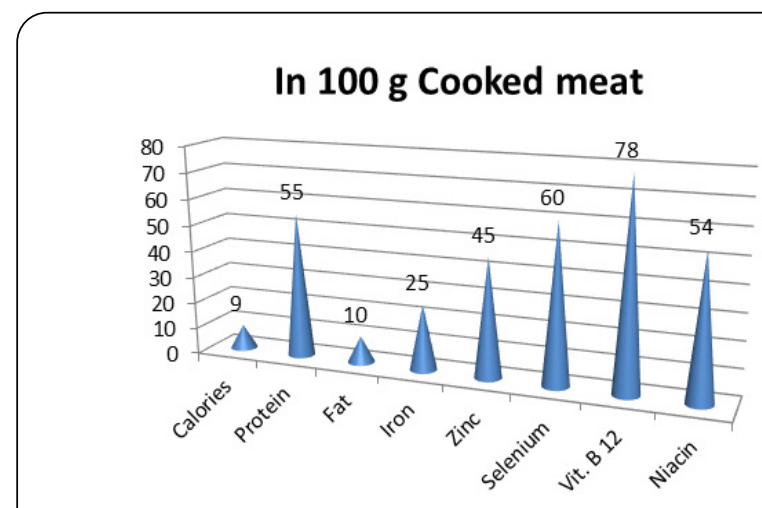

Figure 2: Nutrients in $100 \mathrm{~g}$ cooked meat.

\section{Discussion}

Meat is a controversial issue in the food world. On the one hand, it's a common ingredient in many diets and a good source of protein and other nutrients. Some people, on the other hand, believe that eating it is unhealthy, unethical, and unneeded [26]. This article examines the health advantages and dangers of meat consumption in depth.

Red meat is a nutrient-dense diet that contains significant levels of protein, vital amino acids, vitamins, and minerals, including vitamin A, iron, and zinc, all of which are commonly deficient in the world. However, several studies have connected red meat consumption to a variety of health risks, including heart disease, colon cancer, kidney illness, and digestive disorders $[23,27]$.

To make matters even more complicated, several studies claim that the sort of red meat a person consumes makes the biggest difference. Organic red meat cuts with less fat, such as sirloin steaks or pig tenderloin, may be healthier than others. This is due to the fact that they are unprocessed and contain no added salt, oil, or preservatives. Processed red meats, such as bacon, hot dogs, sausage, bologna, salami, and other similar meats, appear to be the most dangerous to one's health [28].

The link between red meat consumption and colon cancer is most likely explained by epidemiology's inability to detect 
such a small risk, or by a combination of other aspects such as higher obesity, less workout, lower vegetable or nutritional fiber consumption, and possibly other habits that distinguish those who eat the most meat from those who eat the least.

\section{Conclusion}

Meat consumption has been hotly debated in recent years, despite the fact that it is still on the rise internationally. This is motivated by a number of environmental and ethical concerns about meat production and consumption. There are concerns about the economic expenses of meat production, as well as the potential for harm to human and animal welfare and the environment. This chapter expands on these challenges, noting both positive and negative features, and discussing various systems that could assure meat production transparency and sustainability. The chapter finishes with a discussion of future opportunities for more sustainable meat production and their consequences for diverse stakeholders.

\section{Conflict of Interest:}

The authors declare that they have no conflict of interest.

Funding: None.

\section{References}

1. GOP. (2015) Government of Pakistan Milk and meat statistics of Pakistan. Ministry of Food, Agriculture and Livestock, Islamabad, Pakistan.

2. Bashir A, Ahmad F, Mehmood I, Et al. (2015) Economics of red meat production in Punjab. Pak J Agric Res 28: pp. 85-95.

3. Sadiq M (2004) Pakistan poultry sector still. World Poultry 20(8): pp. 10-11.

4. GOP. (2016) Government of Pakistan Milk and meat statistics of Pakistan. Ministry of Food, Agriculture and Livestock, Islamabad, Pakistan.

5. Farouk MM, Pufpaff KM, Amir M (2016) Industrial halal meat production and animal welfare: A review. Meat Sci 120: pp. 60-70.

6. Garnier JP, Klont R, Plastow G (2003) The potential impact of current animal research on the meat industry and consumer attitudes towards meat. Meat Sci 63: pp. 79-80.

7. GOP. (2012) Government of Pakistan Milk and meat statistics of Pakistan. Ministry of Food, Agriculture and Livestock, Islamabad, Pakistan.

8. Tauqir NA, Nawaz H (2001) Performance and Economics of Broiler Chicks Fed on Rations Supplemented with Different Levels of Sodium Bentonite. Int J Agri Biol 3(1): pp. 149-150.

9. Saeed MK, Ahmad I, Sakhawat A, et al. (2009) Comparative evaluation of sorbatox and bentonite for detoxification of aflatoxin contaminated layer feed. Pakistan J Food Sci 19(1-4): pp. 27-31.

10. GOP. (2013) Government of Pakistan Milk and meat statistics of Pakistan. Ministry of Food, Agriculture and Livestock, Islamabad, Pakistan.
11. Aghwan ZA, Bello AU, Abubakar AA, et al. (2016) Efficient halal bleeding, animal handling, and welfare: $A$ holistic approach for meat quality. Meat Sci 121: pp. 420-428.

12. Economic Survey of Pakistan (2014) Ministry of National Food Security and Research. Government of Pakistan, Islamabad, Pakistan.

13. Sahota AW, Bhatti BM (2003) Productive performance of Desi field chickens as affected under deep litter system. Pakistan J Veterinar Res 1(1): pp. 35-38.

14. Chang HS (2007) Overview of the world broiler industry: Implications for the Philippines. Asian J Agri Dev 4: pp. 67-82.

15. Economic Survey of Pakistan (2016) Ministry of National Food Security and Research. Government of Pakistan, Islamabad, Pakistan.

16. Sahota AW, Bhatti BM (2009) Growth performance of different varieties of Desi generation-1 chickens maintained under deep litter system. Pakistan J Veterinar Res 1(1): pp. 4649.

17. Economic Survey of Pakistan (2015) Ministry of National Food Security and Research. Government of Pakistan, Islamabad, Pakistan.

18. FAO (2011) FAO representation in Pakistan. Pakistan and FAO: Achievements and success stories.

19. Anjum AD, Sabri GS, Jamshidi K (1994) Occurrence spread and control of infectious bursal disease in Pakistan. Proceedings of 1st PPA-PVMA Punjab. Int Poultr Conf pp. 57-59.

20. Bruinsma J (2003) World agriculture: Towards 2015/2030. An FAO perspective. Earthscan Publications Ltd, London, UK.

21. Akhtar S (1994) Hydro-pericardium Syndrome in broiler chicken in Pakistan. World's Poultr Sci J 50(2): pp. 177-182.

22. Alahakoon $A U$, Jo $C$, Jayasena $D$ (2016) An overview of meat industry in Sri Lanka: A comprehensive review. Korean J Food Sci An 36: pp. 137-144.

23. ChartsBin statistics collector team (2013) Current Worldwide Annual Meat Consumption per capita.

24. Binnie MA, Barlow K, Johnson V, et al. (2014) Red meats: Time for a paradigm shift in dietary advice. Meat Sci 98: pp. 445-451.

25. Furnols FM, Guerrero L (2014) Consumer preference, behavior and perception about meat and meat products: An overview. Meat Sci 98: pp. 361-371.

26. Elam TE (2006) Projections of global meat production through 2050. Center for Global Food Issues.

27. Farouk MM (2003) Advances in the industrial production of halal and kosher red meat. Meat Sci 95: pp. 805-820.

28. Siddiqui MZ, Qazi MA, Siddique A (1979) Poultry Industry in Pakistan- A Memoe. University of Agriculture, Faisalabad, Pakistan. 